human well-being and economic growth could still take place, but should do so in the least environmentally damaging way, thus being fully 'ecological'.

The Faculty of Human Sciences of London Guildhall University has undertaken a number of environmental initiatives which have served to emphasize the need for a focal point for environmental education and training (particularly related to business) in the London area. These developments have already progressed some way towards establishing the University's credentials in environmental education and training. Some pertinent activities have included:

- A series of conferences and short courses on environmental topics;

- The Careers in the Environment Project;

- Institutional 'Greening' Project;

- Student/public lecture programme;

- Publications on environmental matters including a handbook on careers in the environment and 'Trends in Environmental Education World-wide';
- Development of project proposals in a range of sectoral areas, such as environmental awareness-raising for small and medium-sized enterprises, and training in environmental technology and environmental management.

For more information about the London Environment Centre and forthcoming programmes, contact:

MoNiCA HALE, Director
London Environment Centre
Faculty of Human Sciences
London Guildhall University
Calcutta House
Old Castle Street
London E1 7NT
Englund, UK.
$\quad$ Tel.: +44 171-320-1126/1260
$\quad$ Fix: +44 171-320-1121/1117

\title{
Institute for European Environmental Policy
}

$T$ he Institute for European Environmental Policy (IEEP) is an international network of bodies with the shared goal of analysing and advancing environmental policy in Europe. The Institute was established by the European Cultural Foundation in 1976 and became independent in 1990; but it remains part of the international network of the Foundation. IEEP is also a member of the International Federation of Institutes for Advanced Study.

Since its establishement, IEEP has grown from one office in Bonn to an international network, now comprising five offices with a permanent staff totalling about forty administrative personnel and researchers. This expansion reflects the growing concern for environmental protection especially since the $1970 \mathrm{~s}$, the increasing international dimension of environmental policy and, by no means least, the success of IEEP in responding to these challenges. In particular, it reflects the value of IEEP's international character and its Europe-wide vision of environmental policy issues.

The IEEP Network is structured on the basis of complementary tasks and responsibilities. The Network comprises three main components:

- The supervisory Foundation for European Environmental Policy, Amsterdam (Stichting voor Europees Milieubeleid - STEM);

- The IEEP 'national' offices (at present five, at Arnhem, Bonn, London, Madrid, and Paris); and

- The Advisory Council.

The objective of STEM is to create the conditions necessary for the five 'national' offices to advance environmental policy and practice in Europe. The Board of STEM is international in character, and all its members have long experience in European environmental policy. STEM also owns the rights to use its name of 'Institute for European Environmental Policy' in all European languages.

The main responsibility for research with a view to advancing European environmental policy lies with the five 'national' offices of IEEP. Each office is an autonomous, non-profit, legal entity that is bound to the aims of IEEP in its statutes and through a cooperative agreement with the other offices and with STEM. The chief condition for joining the Network is adherence to this agreement.

IEEP undertakes research on the European dimension of environmental protection, with a major focus on the development, implementation, and evaluation, of the environmental policy of the European Union, international bodies, and national governments. The work of the offices falls into three main categories:

- Carrying out commissioned research with a view to advancing environmental policy and practice in Europe;

- Informing and guiding policymakers, nongovernmental organizations, researchers, professional bodies, and industry; and

- Cooperating with other bodies in the IEEP Network, for example through joint projects and the exchange of information on environmental policy and concomitant developments in Europe.

Since its inception. IEEP has been in the forefront of initiatives aimed at advancing environmental policy in Europe. Much of its work has focused on EC environmental policy; more than sixty projects have been carried out for the European Commission, and a strong record has been built up on Key EU environmental policy issues, such as the environmental policy implications of the internal market and the Treaty of Maastricht, environmental policy instruments, Nature conservation policy, agricultural policy and the environment, and the implementation of EU environmental policy in the Member States.

However, IEEP is also active in the broader framework of European and international environmental policy, working closely with other international organizations (such as the Council of Europe and the European Bank for Reconstruction and Development), and with national governments and other bodies across Europe. For example, in recent years IEEP hals worked in cooperation with more than thirty international organizations and with bodies in over forty countries.

In the early 1980s. IEEP was the first Western European environmental research institute to become active in Central and Eastern Europe. This experience enabled 
IEEP to take on a prominent role in supporting the development of environmental policy in those countries after the revolutionary changes of 1989. IEEP has also for many years studied environmental policy issues in the southern European countries, and more recently has become active in Scandinavia.
GRAHAM BENNETT, IEEP Coordinator

Foundation for European Environmental Policy Jansbuitensingel 7

6811 AA Arnhem

The Netherlands

Tel. +31264422929

Fax +31264453210 .

\section{New Population Numbers Forebode Threat of Water Deficit in Next Century}

$\mathrm{M}$ ore than half of the world's population could live in countries with chronic or recurring water shortages by the middle of the next century, according to new estimates released by Population Action International (PAI). In Sustaining Water: An Update, Authors Robert Engelman \& Pamela LeRoy use new United Nations population projections to extend estimates of per caput availability of renewable fresh water to the year 2050. Under the highest projection, $65 \%$ of the projected world population, or 7.7 thousand million people, would live in 66 countries facing either water scarcity or water stress, whereas under the lowest projection, 3.5 thousand million people would live in 51 water-short countries. The difference between the two figures - 4.2 thousand million people - reflects how different rates of population growth could affect future per caput water availability. Projections of total world population in $A D 2050$ range from a low of 7.9 thousand million people to a high of 11.9 such 'billions'.

The PAI Update also includes revised projections of per caput availability of water in AD 2050 . They indicate that between 2.7 and 3.5 thousand million people could be living in water-stressed or water-scarce countries in just 30 years from now. However, 'The good news is that overall projections of world population for 2025 have gone down', says Engelman, the head of PAI's population and environment programme, whereas 'The bad news is that they have gone up for a number of countries [ that are] already short of renewable water, including Jordin, Egypt, and Saudi Arabia.'

The new figures are also higher for Pakistan, pushing that country into water stress by $\mathrm{AD} 2025$ under all but the lowest population projection. Pakistan's population is projected to be at least 271 million people in AD 2025 - about $10 \%$ higher than was indicated by previous UN figures and more than twice its current size.

\section{Some Countries Improving}

On the other hand, the new population projections for AD 2025 are significantly lower than they were for such water-short countries as Morocco, Iran, Tanzania, and Zimbabwe. For Iran, the projections have gone down by $10 \%$ or more, to between 113 million and 137 million people. So while Iran is still projected to fall into water scarcity by $\mathrm{AD} 2025$ or soon thercafter, per caput water availability could be as much as $20 \%$ higher than under the old projections. Engelman credits the 1989 decision by the Iranian government to support family planning services as a decisive factor in the apparent casing of the country's future water situation.
By AD 2050, however, such countries as Sudan and Niger are projected to enter the ranks of the water-stressed, with per caput water supplies reduced to just one-quarter and one-third, respectively, of their AD 1990 levels. "We are heading into a future of increasing water scarcity', says Engelman. 'But countries [such as] Morocco and Iran demonstrate how greater access to family planning services could help minimize the degree of scarcity in the future.'

The new PAI estimates of per caput water availability update those included in the 1993 study, Sustaining Water: Population and the Future of Renewable Water Supplies. That study used concepts of water stress and water scarcity pioneered by the Swedish hydrologist Malin Falkenmark. Countries with annual, renewable freshwater supplies of less than about 1,700 cubic metres per person will begin to experience periodic or regular water stress, according to Falkenmark's methodology. Those with less than 1,000 cubic metres per person will face water scarcity, and the lack of water may hamper economic development and human well-being. Renewable water is that which falls on or flows naturallyinto a country's territory.

\section{Low, Medium, and High, Population Projections Now Used}

The Update relies upon three new sets of UN projections of future population size, called 'low', 'medium', and 'high', each of which is based on different assumptions about future birth- and death-rates. A total of 149 countries, home to $99 \%$ of current and projected world population, are represented in the Update's estimates of future per caput water supplies.

'Water shortages threaten to undermine both economic development and health for vast numbers of people', says Engelman. 'All of us have a stake in helping countries that face such shortages, both with approaches that conserve water and with family planning and other development programs that can help reduce pressure on this precious and irreplaceable resource.'

Sally ETHElston \& PATRICIA SeARS
Medium Relations
Population Action International
1120 Nineteenth Street NW, Suite 550
Washington
DC 20036-3605, USA.

Tel. 2026591833

Fax 2022931795

Telex 440450 